\title{
Association between leptin, metabolic factors and liver histology in patients with chronic hepatitis C
}

\author{
Robert P Myers MD,2, Djamila Messous $\mathrm{PhD}^{2}$, Thierry Poynard MD PhD², Francoise Imbert-Bismut PhD
}

\begin{abstract}
RP Myers, D Messous, T Poynard, F Imbert-Bismut. Association between leptin, metabolic factors and liver histology in patients with chronic hepatitis C. Can J Gastroenterol 2007;21(5):289-294.
\end{abstract}

BACKGROUND: Steatosis is common in hepatitis C virus (HCV)infected patients and likely accelerates fibrosis progression. Leptin, the peptide product of the obesity gene $(o b)$, has been implicated in hepatic fibrogenesis; circulating levels of leptin correlate with body fat mass. The objective of the present study was to determine the clinical and histological correlates of serum leptin in HCV-infected patients, and to determine its utility in predicting liver histological lesions.

PATIENTS AND METHODS: In 62 patients with chronic HCV, serum leptin was measured using a commercially available immunoassay. Associations between leptin, metabolic parameters, and severe hepatic fibrosis (stages 2 to 4 ) and steatosis (30\% or greater) were determined. The utility of leptin in predicting liver histology was determined using receiver operating characteristic (ROC) curves.

RESULTS: The median body mass index (BMI) was $23.2 \mathrm{~kg} / \mathrm{m}^{2}$ (range $17.7 \mathrm{~kg} / \mathrm{m}^{2}$ to $35.6 \mathrm{~kg} / \mathrm{m}^{2}$ ); $16 \%$ of patients $(\mathrm{n}=10)$ had $\mathrm{HCV}$ genotype 3. Severe fibrosis and steatosis were present in $23 \%$ and $13 \%$ of patients, respectively. Leptin was strongly correlated with the BMI, and its levels were higher in women. BMI-corrected leptin levels were not independently associated with severe fibrosis but were significantly associated with steatosis (OR of 1.07; 95\% CI 1.01 to 1.04). On it own, leptin was poorly predictive of severe steatosis (area under the ROC curve was $0.64 ; 95 \%$ CI 0.42 to 0.87 ). However, its accuracy improved with the addition of HCV genotype (area under the ROC curve was 0.86 ; $95 \%$ CI 0.72 to $1.00 ; \mathrm{P}=0.07$ ).

CONCLUSIONS: As observed in the non-HCV setting, serum leptin correlates with BMI; higher leptin levels are found in women than men with chronic HCV. Serum leptin is a poor predictor of HCV-related fibrosis but may play a role in predicting steatosis when combined with HCV genotype.

Key Words: Fibrosis; Hepatitis; Leptin; Noninvasive; Prediction; Steatosis

\section{L'association entre la leptine, les facteurs métaboliques et l'histologie hépatique chez les patients atteints d'hépatite $\mathrm{C}$ chronique}

\begin{abstract}
HISTORIQUE : La stéatose est courante chez les patients infectés par le virus de l'hépatite $\mathrm{C}$ (VHC) et elle accélère probablement l'évolution de la fibrose. On a constaté la présence de leptine, le produit peptidique du gène de l'obésité $(o b)$ dans des cas de fibrogenèse hépatique. Les taux de leptine qui circulent sont corrélés avec la masse grasse. La présente étude visait à déterminer les corrélats cliniques et histologiques de leptine sérique chez les patients infectés par le VHC et à déterminer leur utilité pour prédire les lésions hépatiques histologiques.
\end{abstract}

PATIENTS ET MÉTHODOLOGIE : Chez 62 patients atteints de VHC chronique, on a mesuré la leptine au moyen d'un dosage immunologique commercial. On a déterminé les associations entre la leptine, les paramètres métaboliques, une grave fibrose hépatique (stades 2 à 4) et la stéatose (30\% ou plus). On a établi l'utilité de la leptine pour prédire l'histologie hépatique au moyen des courbes de fonction d'efficacité du récepteur (FER).

RÉSULTATS : L'indice de masse corporelle (IMC) médian était de $23,2 \mathrm{~kg} / \mathrm{m}^{2}$ (fourchette de $17,7 \mathrm{~kg} / \mathrm{m}^{2}$ à $35,6 \mathrm{~kg} / \mathrm{m}^{2}$ ), $16 \%$ des patients étant infectés par le génotype 3 du VHC. On constatait une fibrose grave et une stéatose chez $23 \%$ et $13 \%$ des patients, respectivement. La leptine était fortement corrélée avec l'IMC, et ses taux étaient plus élevés chez les femmes. Les taux de leptine corrigés par l'IMC n'étaient pas indépendants de la fibrose grave, mais ils étaient significativement associés à une stéatose grave (RR de 1,07; 95 \% IC 1,01 à 1,04). Seule, la leptine était peu prédictive d'une stéatose grave (la zone sous la courbe de FER était de 0,64; $95 \%$ IC 0,42 à 0,87). Cependant, sa précision s'améliorait avec l'ajout du génotype du VHC (la zone sous la courbe de FER était de 0,86; $95 \%$ IC 0,72 à 1,$00 ; \mathrm{P}=0,07)$.

CONCLUSIONS : Comme on l'a observé hors du cadre du VHC, la leptine sérique est corrélée avec l'IMC. On remarque des taux de leptine plus élevés chez les femmes atteintes de VHC chronique que chez les hommes. La leptine sérique est un mauvais prédicteur de fibrose reliée au VHC, mais il peut contribuer à prédire une stéatose lorsqu'elle est combinée à un génotype de VHC.
Chronic hepatitis $\mathrm{C}$ virus (HCV) infection is a major cause of Cirrhosis, end-stage liver disease and hepatocellular carcinoma (1). Approximately $40 \%$ to $80 \%$ of patients have steatosis on liver biopsy (2). The majority of patients (approximately $75 \%$ ) have mild steatosis that affects less than $30 \%$ of hepatocytes. Factors associated with steatosis in chronic HCVinfected patients include genotype 3 infection, alcohol consumption, obesity, hyperlipidemia and insulin resistance (3-5). The impact of steatosis on the course of $\mathrm{HCV}$ is controversial. Accelerated fibrosis progression (4-7) and reduced response to interferon-based therapy $(5,6,8)$ have been reported in some, but not all, studies $(9,10)$.

Leptin is a $16 \mathrm{kDa}$ peptide product of the obesity $(o b)$ gene initially identified by Friedman in 1994 (11). Leptin was identified as the hormone whose absence resulted in morbid obesity and hepatic steatosis in the $o b / o b$ mouse, thus acquiring its name from the Greek word 'leptos' (thin). Rare cases of functional leptin deficiency due to mutations in the gene for leptin (or its receptor) have been reported in humans $(12,13)$. These patients develop morbid obesity that is responsive to leptin replacement

${ }^{1}$ Liver Unit, Division of Gastroenterology, Department of Medicine, University of Calgary, Calgary, Alberta; ${ }^{2}$ Service d'Hépato-Gastro-

Entérologie; ${ }^{3}$ Service de Biochimie, Hôpital La Pitié-Salpêtrière, Paris, France

Correspondence: Dr Robert P Myers, Viral Hepatitis Clinic, G126, 3330 Hospital Drive Northwest, Calgary, Alberta T2N 4N1.

Telephone 403-210-9837, fax 403-210-9368, e-mail rpmyers@ucalgary.ca

Received for publication May 11, 2006. Accepted August 14, 2006 


\section{TABLE 1}

\section{Characteristics of the 62 patients}

\begin{tabular}{lc}
\hline Characteristic & Results \\
\hline Clinical factors & \\
Median age, years (range) & $47(27-70)$ \\
Men, $\mathrm{n}(\%)$ & $35(56)$ \\
Alcohol consumption $\geq 50 \mathrm{~g} /$ day, $\mathrm{n}(\%)$ & $9(15)$ \\
Diabetes, $\mathrm{n}(\%)$ & $3(5)$ \\
Median $\mathrm{BMI}, \mathrm{kg} / \mathrm{m}^{2}(\mathrm{range})$ & $23.2(17.7-35.6)$ \\
Obese $\left(\mathrm{BMI} \geq 30 \mathrm{~kg} / \mathrm{m}^{2}\right), \mathrm{n}(\%)$ & $4(6)$ \\
$\mathrm{HCV}$ genotypes, $\mathrm{n}(\%)$ & \\
1 & $37(60)$ \\
2 & $7(11)$ \\
3 & $10(16)$ \\
$4,5,6$ & $8(13)$ \\
Liver histology, $\mathrm{n}(\%)$ & \\
Severe fibrosis $(\mathrm{F} 2-\mathrm{F} 4)$ & $28(45)$ \\
Cirrhosis $(\mathrm{F} 4)$ & $3(5)$ \\
Severe necroinflammatory activity (A2-A3) & $14(23)$ \\
Severe steatosis $(\geq 30 \%)$ & $8(13)$ \\
\hline
\end{tabular}

BMI Body mass index; HCV Hepatitis C virus

(14). Leptin is expressed primarily by adipocytes, but also in the stomach, placenta and mammary gland (15). Circulating leptin levels correlate closely with the amount of body fat mass. Leptin plays a crucial role in the regulation of appetite and energy expenditure through its effect on the hypothalamus.

Numerous in vitro and in vivo studies (16-18) have shown that leptin plays a role in hepatic steatosis. Patients with alcoholic $(16,17)$ and nonalcoholic fatty liver disease (18) have increased circulating leptin levels in their bodies. The role of leptin in hepatic fibrosis is less clear. Experimental models have shown leptin production by culture-activated hepatic stellate cells and suggest a profibrogenic role, likely mediated by the upregulation of transforming growth factor-beta 1 (19-26). In patients with chronic $\mathrm{HCV}$ infection, data regarding the association between serum leptin and liver histological lesions are conflicting (27-31).

The objectives of the present study were to determine predictors of serum leptin in patients with chronic HCV, to examine the association between serum leptin levels and liver histological lesions, and to evaluate serum leptin as a potential predictor of fibrosis and steatosis for use in clinical practice.

\section{PATIENTS AND METHODS}

\section{Patients and study design}

The patients in the present cross-sectional study belong to a cohort of HCV-infected patients evaluated in the liver unit of the PitiéSalpêtrière Hospital (Paris, France) (32). Chronic HCV was defined as a positive serological test for HCV by at least a second-generation ELISA, positive HCV RNA results by polymerase chain reaction assay and compatible liver biopsy. To be eligible for the study, patients had to be naive to interferon-based treatment, and have an interpretable liver biopsy and fasting serum sample drawn within six months of the biopsy and stored at $-80^{\circ} \mathrm{C}$. Exclusion criteria included hepatitis B or HIV coinfection, coexistent nonviral liver disease and prior organ transplantation. All patients consented to the use of clinical data and serum for research purposes.

\section{Data collection}

For all patients in the cohort, a questionnaire of 129 items, including sociodemographic, clinical, virological, histological and treatmentrelated information, was completed (32). For the purpose of the present study, demographics, daily alcohol consumption (average intake over the preceding five years), anthropometric measurements (weight, height and body mass index [BMI]) and diabetes mellitus history were recorded. Fasting serum samples were tested for glucose, total cholesterol, triglycerides and leptin levels. Leptin was measured by a commercially available ELISA (Quantikine, R\&D Systems Inc, USA). The sensitivity of this assay is $7.8 \mathrm{pg} / \mathrm{mL}$; reported intra- and interassay coefficients of variation do not exceed 5.4\% (Quantikine package insert, catalog \#DLP00). All patients had HCV genotyping by the Inno-LiPA line probe assay (Innogenetics, Belgium).

\section{Liver histology}

Liver biopsies were fixed, paraffin embedded and stained for collagen with hematoxylin-eosin-safran, and Masson's trichrome or picrosirius red. A single pathologist blinded to patient characteristics and laboratory results analyzed the biopsies according to the METAVIR classification $(33,34)$. Fibrosis was staged from F0 to F4: F0, no fibrosis; F1, portal fibrosis without septa; F2, portal fibrosis with few septa; F3, numerous septa without cirrhosis; and F4, cirrhosis. Necroinflammatory activity was graded from A0 to A3: A0, no activity; A1, mild activity; A2, moderate activity and A3, severe activity. Fibrosis stages F2 to F4 and activity grades A2 to A3 were considered severe. Steatosis was graded as mild if less than $30 \%$ of hepatocytes were affected; otherwise, it was considered severe (2).

\section{Statistical analysis}

Quantitative data are expressed as medians (ranges) or proportions. Univariate associations were determined using Pearson's correlations, logistic regression, and Mann-Whitney $U$ and Fisher's exact tests, as appropriate. Multivariate logistic regression analyses were also used. Receiver operating characteristics curves (ROCs) were constructed to determine the predictive utilities of various models for the identification of severe steatosis and fibrosis. The area under the ROC (AUROC) curves was compared using DeLong et al's (35) method. $\mathrm{P} \leq 0.05$ was considered significant. STATA 8.0 software (Stata Corporation, USA) was used for all analyses.

\section{RESULTS}

\section{Patients}

Sixty-two patients were included in the study (Table 1). The median age was 47 years (range 27 to 70 years); $56 \%$ were men. Three patients $(5 \%)$ were diabetic; all three were on hypoglycemic medication and had normal fasting glucose levels. The median BMI was $23.2 \mathrm{~kg} / \mathrm{m}^{2}\left(17.7 \mathrm{~kg} / \mathrm{m}^{2}\right.$ to $\left.35.6 \mathrm{~kg} / \mathrm{m}^{2}\right)$; only $6 \%$ $(\mathrm{n}=4)$ were obese (BMI of $30 \mathrm{~kg} / \mathrm{m}^{2}$ or greater). The majority (60\%) were infected with genotype $1 ; 10$ patients $(16 \%)$ had genotype 3 . The prevalences of severe fibrosis, inflammation and steatosis were $45 \%, 23 \%$ and $13 \%$, respectively.

\section{Serum leptin in $\mathrm{HCV}$ and its determinants}

Leptin levels varied over a wide range (median $11.3 \mathrm{ng} / \mathrm{mL}$, range $1.0 \mathrm{ng} / \mathrm{mL}$ to $99.3 \mathrm{ng} / \mathrm{mL}$ ) and correlated significantly with the BMI $(r=0.57, \mathrm{P}<0.0005)$. This correlation was more pronounced in women than men (women: $\mathrm{r}=0.83, \mathrm{P}<0.0005$; men: $\mathrm{r}=0.49$, $\mathrm{P}=0.003$; Figure 1). Due to the strong association between serum leptin and BMI, further analyses consider leptin levels adjusted for BMI unless otherwise indicated. The leptin/BMI ratio was significantly higher in women than men (median $0.78 \mathrm{ng} / \mathrm{mL} \cdot \mathrm{m}^{2} / \mathrm{kg}$ 


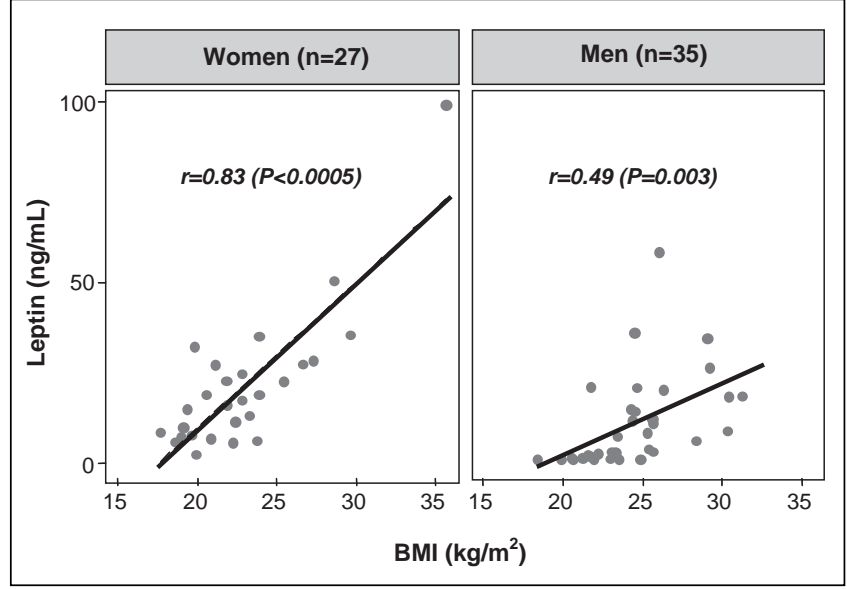

Figure 1) Correlation between serum leptin, body mass index (BMI) and sex in chronic hepatitis $C$ virus-infected patients. Serum leptin is strongly correlated with BMI, particularly in women

\section{TABLE 2} Leptin/body mass index ratio according to the severity of
histological lesions and genotype

\begin{tabular}{llll}
\hline Histological lesion* & $\begin{array}{c}\text { Mild, } \\
\text { median (range) }\end{array}$ & $\begin{array}{c}\text { Severe, } \\
\text { median (range) }\end{array}$ & $\mathbf{P}^{*}$ \\
\hline Necroinflammatory activity & & & \\
All patients $(\mathrm{n}=62 ; 48 / 14)$ & $0.48(0.04-2.79)$ & $0.61(0.05-1.47)$ & 0.27 \\
Genotype $3(\mathrm{n}=10 ; 8 / 2)$ & $0.31(0.04-0.80)$ & $0.46(0.33-0.60)$ & 0.79 \\
$\quad$ Nongenotype $3(\mathrm{n}=52 ; 40 / 12)$ & $0.48(0.04-2.79)$ & $0.74(0.05-1.47)$ & 0.36 \\
Fibrosis & & & \\
All patients $(\mathrm{n}=62 ; 34 / 28)$ & $0.46(0.04-2.25)$ & $0.59(0.04-2.79)$ & 0.23 \\
Genotype 3 $(\mathrm{n}=10 ; 4 / 6)$ & $0.76(0.29-0.80)$ & $0.23(0.04-0.60)$ & 0.06 \\
$\quad$ Nongenotype 3 $(\mathrm{n}=52 ; 30 / 22)$ & $0.42(0.04-2.25)$ & $0.81(0.76-2.79)$ & 0.03 \\
Steatosis & & & \\
All patients $(\mathrm{n}=62 ; 54 / 8)$ & $0.45(0.04-1.76)$ & $0.76(0.04-2.79)$ & 0.19 \\
Genotype 3 $(\mathrm{n}=10 ; 6 / 4)$ & $0.33(0.07-0.80)$ & $0.51(0.04-0.78)$ & 1.0 \\
$\quad$ Nongenotype 3 $(\mathrm{n}=52 ; 48 / 4)$ & $0.48(0.04-1.76)$ & $1.65(0.51-2.79)$ & 0.03 \\
\hline
\end{tabular}

*Numbers in parentheses indicate total number of patients and number of patients with mild/severe lesions

versus $0.23 \mathrm{ng} / \mathrm{mL} \cdot \mathrm{m}^{2} / \mathrm{kg} ; \mathrm{P}=0.0002$ ). There were no associations between the leptin/BMI ratio (or absolute leptin; data not shown) and total cholesterol $(r=0.05, P=0.72)$ or fasting glucose levels $(\mathrm{r}=0.13, \mathrm{P}=0.31)$. The median leptin/BMI ratios were similar in diabetics and nondiabetics $\left(0.32 \mathrm{ng} / \mathrm{mL} \cdot \mathrm{m}^{2} / \mathrm{kg}\right.$ versus $0.51 \mathrm{ng} / \mathrm{mL} \cdot \mathrm{m}^{2} / \mathrm{kg} ; \mathrm{P}=0.30$ ). The leptin/BMI ratio was weakly correlated with serum triglycerides $(\mathrm{r}=0.26, \mathrm{P}=0.04)$. There was no association with HCV genotype ( $\chi^{2}$ [five degrees of freedom] $=4.73 ; \mathrm{P}=0.45)$; leptin/BMI ratios were similar in patients with genotype 3 and nongenotype $3\left(0.33 \mathrm{ng} / \mathrm{mL} \cdot \mathrm{m}^{2} / \mathrm{kg}\right.$ versus $0.50 \mathrm{ng} / \mathrm{mL} \cdot \mathrm{m}^{2} / \mathrm{kg} ; \mathrm{P}=0.31$ ).

Association between leptin, fibrosis and necroinflammation The association between BMI-corrected leptin levels and liver histological lesions is summarized in Table 2. In univariate analysis including all patients, irrespective of genotype, the leptin/BMI ratio was not associated with the severity of necroinflammation $(\mathrm{P}=0.27)$ or fibrosis $(\mathrm{P}=0.23)$. In nongenotype 3 patients, median leptin/BMI ratios were higher in those with severe $(n=52)$ versus mild $(\mathrm{n}=10)$ fibrosis $(\mathrm{P}=0.03)$. This association was not observed in genotype 3 patients (Table 2; Figure 2). Moreover, in a

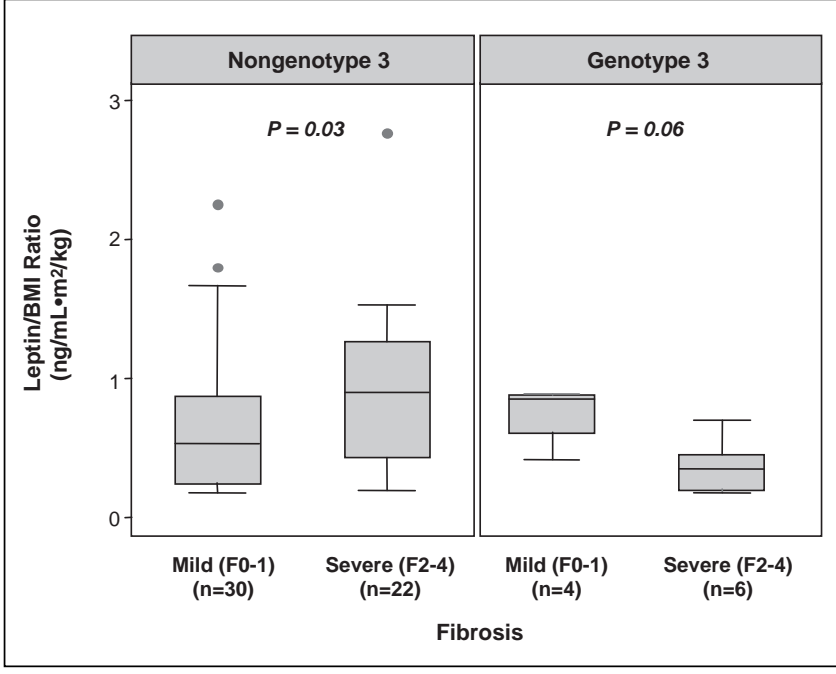

Figure 2) Box plots illustrating the association between body mass index (BMI)-corrected leptin levels and hepatic fibrosis in patients with chronic hepatitis C stratified by genotype. FO No fibrosis; F1 Portal fibrosis without septa; F2 Portal fibrosis with few septa; F3 Numerous septa without cirrhosis; F4 Cirrhosis

multivariate logistic regression analysis controlling for age, sex, daily alcohol consumption and BMI (known factors associated with fibrosis), serum leptin was not independently associated with severe fibrosis $(\mathrm{OR}=1.03 ; 95 \%$ CI 0.98 to 1.09 ; $\mathrm{P}=0.28)$. The AUROC of serum leptin as a predictor of severe fibrosis was only 0.58 ( $95 \%$ CI 0.44 to 0.73 ), not significantly different from chance alone. Only age at biopsy was significant in this analysis ( $\mathrm{OR}=1.10 ; 95 \%$ CI 1.04 to $1.17 ; \mathrm{P}=0.002)$.

\section{Predictors of hepatic steatosis}

Clinical and biochemical predictors of severe steatosis are outlined in Table 3. In univariate analysis, only leptin, the leptin/BMI ratio and genotype 3 were significant. Severe steatosis was present in $40 \%$ (four of 10 ) of patients with genotype 3 versus $8 \%$ (four of 52 ) of nongenotype 3 patients $(\mathrm{P}=0.005)$. In multivariate analysis controlling for genotype and BMI, serum leptin was independently associated with severe steatosis $(\mathrm{OR}=1.07 ; 95 \% \mathrm{CI} 1.01$ to $1.04 ; \mathrm{P}=0.01)$. Genotype 3 infection was significant $(\mathrm{OR}=28.8 ; 95 \% \mathrm{CI} 3.18$ to $261 ; \mathrm{P}=0.003)$, whereas $\mathrm{BMI}$ was not $(\mathrm{OR}=0.87 ; 95 \% \mathrm{CI} 0.66$ to $1.16 ; \mathrm{P}=0.36)$.

Due to the strong effect of genotype 3 on steatosis, a stratified analysis of leptin/BMI ratios according to genotype was performed (Table 2). In patients with genotype 3 , no association was observed between the leptin/BMI ratio and steatosis $(\mathrm{P}=1.0)$. However, in patients with nongenotype 3 , higher median leptin/BMI ratios were observed in the presence of severe steatosis $(\mathrm{P}=0.03)$ (Figure 3$)$.

Serum leptin for the prediction of severe steatosis

To determine whether serum leptin could be used as a predictive tool for identifying severe steatosis, an index was created using the logistic regression model. The AUROC for this index was 0.64 (95\% CI 0.42 to 0.87 ), indicative of poor predictive utility (Figure 4). At an optimally sensitive cut-off point of leptin $(8.8 \mathrm{ng} / \mathrm{mL}$ or greater), the sensitivity, specificity and accuracy were only $87.5 \%$ (seven of eight patients), $50 \%$ (27 of 54 patients) and $54.8 \%$ (34 of 62 patients), respectively. The 
TABLE 3

Clinical and biochemical predictors of severe steatosis $(\geq 30 \%)$ as determined by univariate and multivariate logistic regression analyses

\begin{tabular}{|c|c|c|c|c|}
\hline \multirow[b]{2}{*}{ Variable } & \multicolumn{2}{|c|}{ Univariate analysis } & \multicolumn{2}{|c|}{ Multivariate analysis* } \\
\hline & OR (95\% Cl) & $\mathbf{P}$ & OR $(95 \% \mathrm{Cl})$ & $\mathbf{P}$ \\
\hline \multicolumn{5}{|l|}{ Clinical factors $^{\dagger}$} \\
\hline Men & $0.41(0.09-1.91)$ & 0.26 & - & - \\
\hline Alcohol consumption $\geq 50 \mathrm{~g} /$ day & $2.24(0.37-13.36)$ & 0.38 & - & - \\
\hline Body mass index & $1.12(0.92-1.36)$ & 0.25 & $0.87(0.66-1.16)$ & 0.36 \\
\hline Leptin/body mass index ratio & $3.54(1.09-11.46)$ & 0.04 & - & - \\
\hline Triglycerides & $2.08(0.77-5.64)$ & 0.15 & - & - \\
\hline Cholesterol & $0.92(0.53-1.61)$ & 0.77 & - & - \\
\hline Glucose & $1.18(0.66-2.09)$ & 0.58 & - & - \\
\hline Genotype 3 & $8.00(1.58-40.63)$ & 0.01 & $28.8(3.18-261)$ & 0.003 \\
\hline
\end{tabular}

${ }^{*}$ Only leptin, obesity and genotype 3 were included in the multivariate analysis; ${ }^{\dagger}$ Diabetes mellitus was excluded from the analysis because none of the diabetic patients $(n=3)$ had severe steatosis

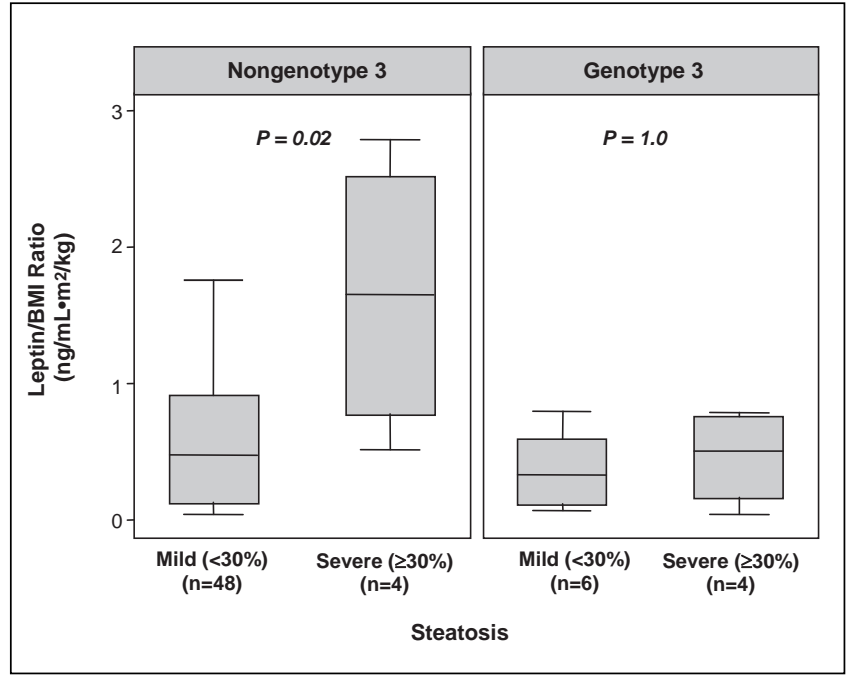

Figure 3) Box plots illustrating the association between body mass index (BMI)-corrected leptin levels and hepatic steatosis in patients with chronic hepatitis $\mathrm{C}$ stratified by genotype

positive and negative predictive values were $20.6 \%$ (seven of 34 patients) and $96.4 \%$ (27 of 28 patients), respectively. The AUROC for serum leptin was higher in patients with nongenotype $3(0.82 ; 95 \% \mathrm{Cl} 0.59$ to 1.00$)$ than in those with genotype 3 (0.50; $95 \%$ CI 0.05 to 0.95$)$; however, this difference was not significant $(\mathrm{P}=0.21)$. A model including genotype in combination with leptin $(0.86 ; 95 \%$ CI 0.72 to $1.00 ; \mathrm{P}=0.07)$ had enhanced predictive accuracy (appendix shows formulas of predictive models).

\section{DISCUSSION}

In the present study, we describe the association between serum leptin, metabolic factors and liver histology in patients with chronic HCV. As observed in the non-HCV setting, leptin levels correlate strongly with BMI even in our relatively nonobese HCV patients. In a landmark study, Considine et al (36) demonstrated that this finding is due to the induction of $o b$ gene expression, which signals the central nervous system to regulate

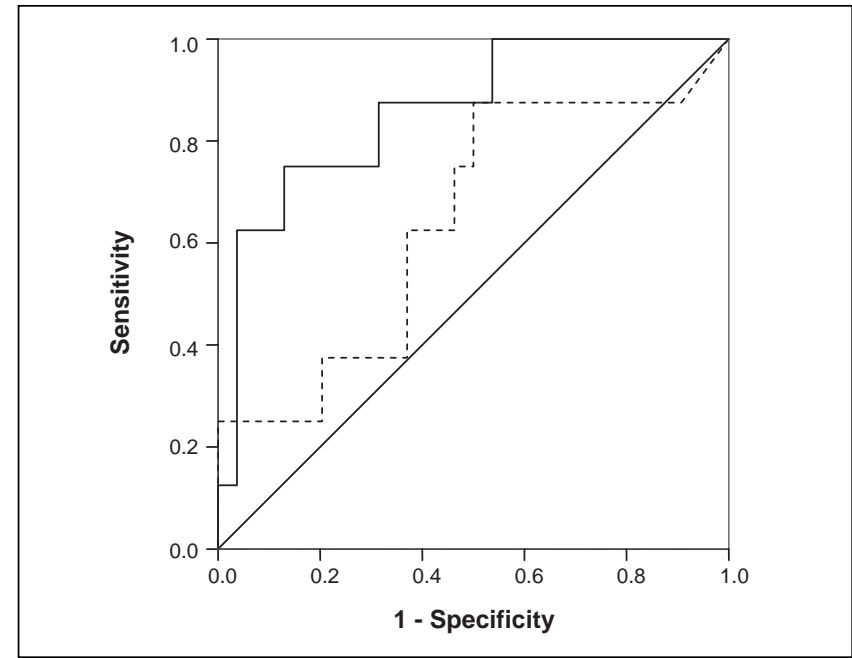

Figure 4) Receiver operating characteristic (ROC) curve of indexes including serum leptin (dashed line) and leptin plus genotype (solid line), for the prediction of severe steatosis (30\% or greater). The area under the ROC curve of leptin plus genotype was higher than that of leptin alone $(0.86$ versus $0.64 ; P=0.07)$. The solid diagonal line indicates that predicted by chance alone (area under the ROC curve of 0.50 )

caloric intake and energy expenditure in response to body fat stores. As previously reported $(27,28,30,37)$, serum leptin levels were approximately twofold higher in women than men, even after adjustment for the BMI. The mechanism for this difference is unclear, but may relate to differential body fat distribution (ie, greater amounts of subcutaneous adipose tissue than visceral adipose tissue in women) or the effects of sex steroids (38-40). We did not observe an association between leptin and features of the metabolic syndrome (total cholesterol levels, fasting glucose levels or diabetes), other than a weak correlation with serum triglycerides.

Our primary objective was to examine the association between leptin and HCV-related histological lesions. Overall, leptin was not associated with hepatic necroinflammation or fibrosis. The relationship between leptin and fibrosis is controversial; however, in vitro studies (19-26) have clearly 
demonstrated a role in profibrogenic responses within the liver. For example, activated hepatic stellate cells, the main fibrogenic cell type within the liver, express leptin and its receptor, and when treated with leptin, show increased collagen production (19-22). Moreover, injected leptin leads to a greater expression of procollagen type 1 , transforming growth factor-beta 1 and alphasmooth muscle actin in animal models of fibrosis $(23,24)$. Finally, leptin-deficient $(o b / o b)$ mice and leptin-resistant $(f a / f a)$ rats are protected from experimentally induced liver fibrosis $(25,26)$. Human studies describing the role of leptin in fibrosis are less convincing. In patients with nonalcoholic fatty liver disease, Angulo et al (18) reported a univariate association between leptin and fibrosis, which was abolished by adjustment for confounding factors. In patients with chronic HCV, an association between serum leptin and fibrosis has been reported in some (27-29), but not all (30,31), studies. In our study, BMI-corrected leptin levels were higher in patients with advanced fibrosis and nongenotype 3. In a multivariate analysis, controlling for factors known to affect HCV-related fibrosis progression, leptin was not significant. Because the sample size was small, we interpret these results with caution because we cannot exclude confounding by other factors. It is also possible that leptin levels intrahepatically, rather than in the serum, are more important determinants of hepatic fibrosis.

We also observed higher BMI-adjusted serum leptin levels in patients with severe steatosis (30\% or greater) having nongenotype 3 only. These data support the concept that steatosis in genotype 3 patients is predominantly due to the cytopathic effect of the virus (so-called 'viral steatosis'), whereas metabolic factors are more important in patients with other genotypes ('metabolic steatosis') (3,5). Indeed, improvement in steatosis following successful antiviral therapy is more common in genotype 3 patients $(5,41)$. In those with a sustained virological response to antiviral therapy, improvement and resolution of steatosis have been reported in $77 \%$ and $46 \%$ of genotype 3 patients, respectively, and in only $46 \%$ and $29 \%$ of patients with nongenotype 3 (5). Although a wealth of literature has examined surrogate markers of HCV-related fibrosis, analogous studies for steatosis are limited. In our study, the AUROC of leptin for severe steatosis was only 0.64, indicating limited utility. However, the accuracy was greater in patients with nongenotype 3 (AUROC was 0.82 versus 0.50 ) and improved with addition of HCV genotype (AUROC was 0.86). These data suggest that leptin may be useful, particularly in nongenotype 3 patients, for the identification of 'metabolic steatosis' that may improve with management of metabolic risk factors.

In terms of other surrogate markers of steatosis, Poynard et al (42) recently derived and validated a novel combination of markers (SteatoTest, Biopredictive, France). This index combines the six biochemical components of the FibroTest-ActiTest (Biopredictive, France) with BMI, cholesterol, triglycerides and glucose. For the prediction of steatosis of $5 \%$ or greater, the SteatoTest had AUROCs of 0.80 to 0.86 in cohorts of HCVinfected patients before and after successful antiviral therapy. The AUROCs for severe steatosis (30\% or greater, as defined in our study) were similar and genotype did not affect the performance of the model ( $\mathrm{T}$ Poynard, personal communication). If externally validated, the SteatoTest may prove useful for the noninvasive evaluation of HCV-related steatosis. In another recent study (43), lipid peroxidation products and antioxidants were poorly predictive of steatosis. Other modalities, including imaging techniques, are limited by poor sensitivity and specificity (eg, ultrasound), high cost and/or limited availability (eg, magnetic resonance spectroscopy).

On a more philosophical note, one could argue whether noninvasive markers of HCV-related steatosis are truly necessary. Although there is no specific treatment for hepatic steatosis, improvements may occur following antiviral therapy and weight loss. Hickman et al (44) reported reduced steatosis and improved liver biochemistry and fibrosis in $\mathrm{HCV}$-infected patients enrolled in a three-month weight loss program. Because patients with persistent viremia are at risk of progressive fibrosis, which is likely accelerated by steatosis, and steatosis may interfere with response to antiviral therapy, some have advocated that overweight HCV patients be encouraged to lose weight in an attempt to improve outcomes. If this strategy proves beneficial, accurate identification of surrogate markers will be useful to longitudinally evaluate changes in steatosis.

Our study has several limitations. Most importantly, the small sample size limits any firm conclusions, particularly based on the multivariate and some subgroup analyses. In addition, our study was retrospective and cross-sectional. A prospective study with serial liver biopsies is necessary to truly assess the impact of serum leptin on the natural history of HCV infection. Finally, our study population consisted of French patients with chronic HCV, and thus, generalizability to other populations requires further study. In our study (and as reported in another French study [10]), the median BMI was $23.2 \mathrm{~kg} / \mathrm{m}^{2}$, and only $6 \%$ of patients were obese. In a recent American study (7), the median BMI was $28.5 \mathrm{~kg} / \mathrm{m}^{2}$ and $32 \%$ were obese. Our small number of obese patients likely explains the failure to find an independent association between obesity and steatosis or fibrosis. Finally, the assay we used measures total serum leptin, which is composed of free and proteinbound components (15). We cannot exclude a beneficial role for measurement of these specific components.

\section{CONCLUSIONS}

Serum leptin levels in patients with chronic HCV correlate with BMI and are higher in women. BMI-adjusted levels tend to be higher in patients with nongenotype 3 and severe fibrosis or steatosis. Although the clinical utility of serum leptin alone for predicting liver histology is limited, an index combining leptin with HCV genotype appears promising for assessing steatosis.

ACKNOWLEDGEMENTS: Dr Myers is supported by a Clinical Investigator Award from the Alberta Heritage Foundation for Medical Research.

CONFLICT OF INTEREST: Dr Poynard has a commercial interest in Biopredictive (Paris, France), the company marketing the SteatoTest.

\section{APPENDIX}

The logistic regression models for the steatosis indexes are as follows:

$$
\begin{aligned}
& \text { 1) Leptin index }=\frac{1}{1+\exp (2.71404-0.041667 \bullet[\text { leptin }])} \\
& \text { 2) Leptin /genotype }=\frac{1}{1+\exp (4.238443-0.06966 \bullet[\text { leptin] }-3.12569 \bullet[\text { genotype }])}
\end{aligned}
$$

Where leptin is measured in $\mathrm{ng} / \mathrm{mL}$, genotype $3=1$ and nongenotype $3=0$. 


\section{REFERENCES}

1. Lauer GM, Walker BD. Hepatitis C virus infection. N Engl J Med 2001;345:41-52.

2. Asselah T, Rubbia-Brandt L, Marcellin P, Negro F. Steatosis in chronic hepatitis C: Why does it really matter? Gut 2006;55:123-30.

3. Rubbia-Brandt L, Quadri R, Abid K, et al. Hepatocyte steatosis is a cytopathic effect of hepatitis $\mathrm{C}$ virus genotype 3. J Hepatol 2000;33:106-15.

4. Rubbia-Brandt L, Fabris P, Paganin S, et al. Steatosis affects chronic hepatitis $\mathrm{C}$ progression in a genotype specific way. Gut 2004;53:406-12.

5. Poynard T, Ratziu V, McHutchison J, et al. Effect of treatment with peginterferon or interferon alfa-2b and ribavirin on steatosis in patients infected with hepatitis C. Hepatology 2003;38:75-85.

6. Patton HM, Patel K, Behling C, et al. The impact of steatosis on disease progression and early and sustained treatment response in chronic hepatitis C patients. J Hepatol 2004;40:484-90.

7. Monto A, Alonzo J, Watson JJ, Grunfeld C, Wright TL. Steatosis in chronic hepatitis C: Relative contributions of obesity, diabetes mellitus, and alcohol. Hepatology 2002;36:729-36.

8. Bjoro K, Bell H, Hellum KB, et al. Effect of combined interferon-alpha induction therapy and ribavirin on chronic hepatitis $\mathrm{C}$ virus infection: A randomized multicentre study. Scand J Gastroenterol 2002;37:226-32.

9. Bressler BL, Guindi M, Tomlinson G, Heathcote J. High body mass index is an independent risk factor for nonresponse to antiviral treatment in chronic hepatitis C. Hepatology 2003;38:639-44.

10. Asselah T, Boyer N, Guimont MC, et al. Liver fibrosis is not associated with steatosis but with necroinflammation in French patients with chronic hepatitis C. Gut 2003;52:1638-43.

11. Zhang Y, Proenca R, Maffei M, Barone M, Leopold L, Friedman JM. Positional cloning of the mouse obese gene and its human homologue. Nature 1994;372:425-32. (Erratum in 1995;374:479).

12. Strobel A, Issad T, Camoin L, Ozata M, Strosberg AD. A leptin missense mutation associated with hypogonadism and morbid obesity. Nat Genet 1998;18:213-5.

13. Ozata M, Ozdemir IC, Licinio J. Human leptin deficiency caused by a missense mutation: Multiple endocrine defects, decreased sympathetic tone, and immune system dysfunction indicate new targets for leptin action, greater central than peripheral resistance to the effects of leptin, and spontaneous correction of leptin-mediated defects. J Clin Endocrinol Metab 1999;84:3686-95. (Erratum in 2000;85:416).

14. Farooqi IS, Jebb SA, Langmack G, et al. Effects of recombinant leptin therapy in a child with congenital leptin deficiency. N Engl J Med 1999;341:879-84.

15. Chan JL, Mantzoros CS. Role of leptin in energy-deprivation states: Normal human physiology and clinical implications for hypothalamic amenorrhoea and anorexia nervosa. Lancet 2005;366:74-85.

16. McCullough AJ, Bugianesi E, Marchesini G, Kalhan SC. Gender-dependent alterations in serum leptin in alcoholic cirrhosis. Gastroenterology 1998;115:947-53.

17. Henriksen JH, Holst JJ, Moller S, Brinch K, Bendtsen F. Increased circulating leptin in alcoholic cirrhosis: Relation to release and disposal. Hepatology 1999;29:1818-24.

18. Angulo P, Alba LM, Petrovic LM, Adams LA, Lindor KD, Jensen MD. Leptin, insulin resistance, and liver fibrosis in human nonalcoholic fatty liver disease. J Hepatol 2004;41:943-9.

19. Potter JJ, Womack L, Mezey E, Anania FA. Transdifferentiation of rat hepatic stellate cells results in leptin expression. Biochem Biophys Res Commun 1998;244:178-82. (Erratum in 1998;248:441).

20. Saxena NK, Ikeda K, Rockey DC, Friedman SL, Anania FA. Leptin in hepatic fibrosis: Evidence for increased collagen production in stellate cells and lean littermates of ob/ob mice. Hepatology 2002;35:762-71.

21. Saxena NK, Saliba G, Floyd JJ, Anania FA. Leptin induces increased alpha2(I) collagen gene expression in cultured rat hepatic stellate cells. J Cell Biochem 2003;89:311-20.

22. Otte C, Otte JM, Strodthoff D, et al. Expression of leptin and leptin receptor during the development of liver fibrosis and cirrhosis. Exp Clin Endocrinol Diabetes 2004;112:10-7.

23. Zwirska-Korczala K, Dziambor AP, Wiczkowski A, Berdowska A, Gajewska K, Stolarz W. [Hepatocytes growth factor (HGF), leptin, neopterin serum concentrations in patients with chronic hepatitis C]. Przegl Epidemiol 2001;55 Suppl 3:164-9.

24. Ikejima $\mathrm{K}$, Takei $\mathrm{Y}$, Honda $\mathrm{H}$, et al. Leptin receptor-mediated signaling regulates hepatic fibrogenesis and remodeling of extracellular matrix in the rat. Gastroenterology 2002;122:1399-410.

25. Honda H, Ikejima K, Hirose M, et al. Leptin is required for fibrogenic responses induced by thioacetamide in the murine liver. Hepatology 2002;36:12-21.

26. Sakaida I, Jinhua S, Uchida K, Terai S, Okita K. Leptin receptor-deficient Zucker ( $\mathrm{fa} / \mathrm{fa}$ ) rat retards the development of pig serum-induced liver fibrosis with Kupffer cell dysfunction. Life Sci 2003;73:2491-501.

27. Piche T, Vandenbos F, Abakar-Mahamat A, et al. The severity of liver fibrosis is associated with high leptin levels in chronic hepatitis C. J Viral Hepat 2004;11:91-6.

28. Crespo J, Rivero M, Fabrega E, et al. Plasma leptin and TNF-alpha levels in chronic hepatitis $\mathrm{C}$ patients and their relationship to hepatic fibrosis. Dig Dis Sci 2002;47:1604-10.

29. Testa R, Franceschini R, Giannini E, et al. Serum leptin levels in patients with viral chronic hepatitis or liver cirrhosis. J Hepatol 2000;33:33-7.

30. Giannini E, Ceppa P, Botta F, et al. Leptin has no role in determining severity of steatosis and fibrosis in patients with chronic hepatitis $\mathrm{C}$. Am J Gastroenterol 2000;95:3211-7.

31. Widjaja A, Wedemeyer H, Tillmann HL, et al. Hepatitis C and the leptin system: Bound leptin levels are elevated in patients with hepatitis $\mathrm{C}$ and decrease during antiviral therapy. Scand J Gastroenterol 2001;36:426-31.

32. Poynard T, Bedossa P, Opolon P. Natural history of liver fibrosis progression in patients with chronic hepatitis C. The OBSVIRC, METAVIR, CLINIVIR, and DOSVIRC groups. Lancet 1997;349:825-32.

33. Intraobserver and interobserver variations in liver biopsy interpretation in patients with chronic hepatitis C. The French METAVIR Cooperative Study Group. Hepatology 1994;20:15-20.

34. Bedossa P, Poynard T. An algorithm for the grading of activity in chronic hepatitis C. The METAVIR Cooperative Study Group. Hepatology 1996;24:289-93.

35. DeLong ER, DeLong DM, Clarke-Pearson DL. Comparing the areas under two or more correlated receiver operating characteristic curves: A nonparametric approach. Biometrics 1988;44:837-45.

36. Considine RV, Sinha MK, Heiman ML, et al. Serum immunoreactiveleptin concentrations in normal-weight and obese humans. N Engl J Med 1996;334:292-5.

37. Romero-Gomez M, Castellano-Megias VM, Grande L, et al. Serum leptin levels correlate with hepatic steatosis in chronic hepatitis C. Am J Gastroenterol 2003;98:1135-41.

38. Couillard C, Mauriege P, Prud'homme D, et al. Plasma leptin concentrations: Gender differences and associations with metabolic risk factors for cardiovascular disease. Diabetologia 1997;40:1178-84.

39. Rosenbaum M, Pietrobelli A, Vasselli JR, Heymsfield SB, Leibel RL. Sexual dimorphism in circulating leptin concentrations is not accounted for by differences in adipose tissue distribution. Int J Obes Relat Metab Disord 2001;25:1365-71.

40. Saad MF, Damani S, Gingerich RL, et al. Sexual dimorphism in plasma leptin concentration. J Clin Endocrinol Metab 1997;82:579-84.

41. Kumar D, Farrell GC, Fung C, George J. Hepatitis C virus genotype 3 is cytopathic to hepatocytes: Reversal of hepatic steatosis after sustained therapeutic response. Hepatology 2002;36:1266-72.

42. Poynard T, Ratziu V, Naveau S, et al. The diagnostic value of biomarkers (SteatoTest) for the prediction of liver steatosis. Comp Hepatol 2005;4:10.

43. Bonnefont-Rousselot D, Ratziu V, Giral P, et al. Blood oxidative stress markers are unreliable markers of hepatic steatosis. Aliment Pharmacol Ther 2006;23:91-8.

44. Hickman IJ, Clouston AD, Macdonald GA, et al. Effect of weight reduction on liver histology and biochemistry in patients with chronic hepatitis C. Gut 2002;51:89-94. 


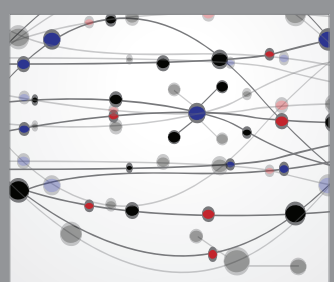

The Scientific World Journal
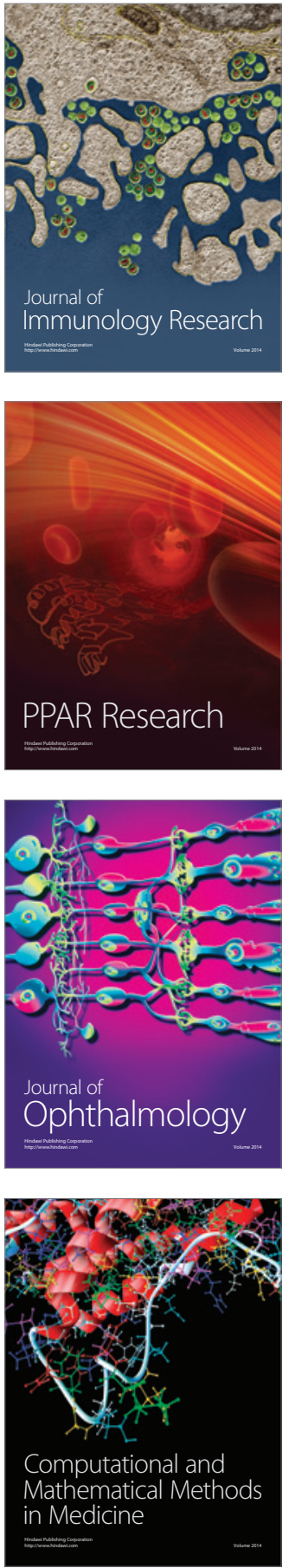

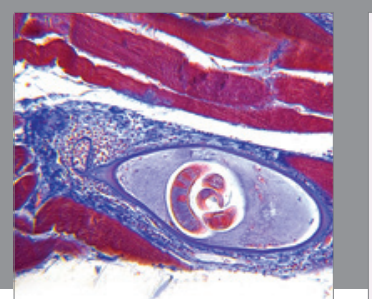

Gastroenterology Research and Practice

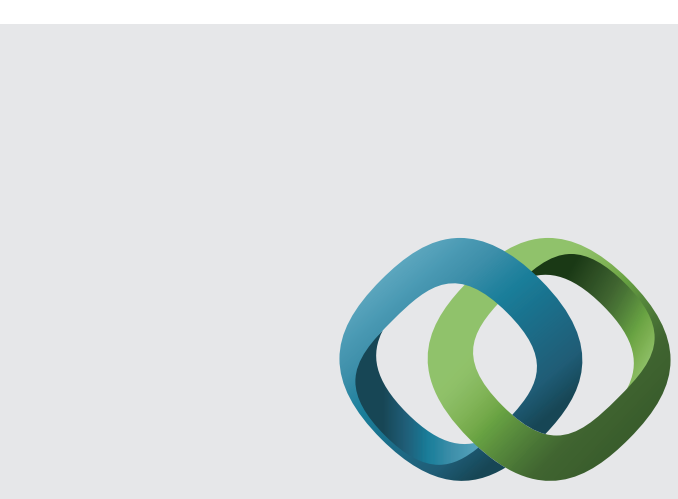

\section{Hindawi}

Submit your manuscripts at

http://www.hindawi.com
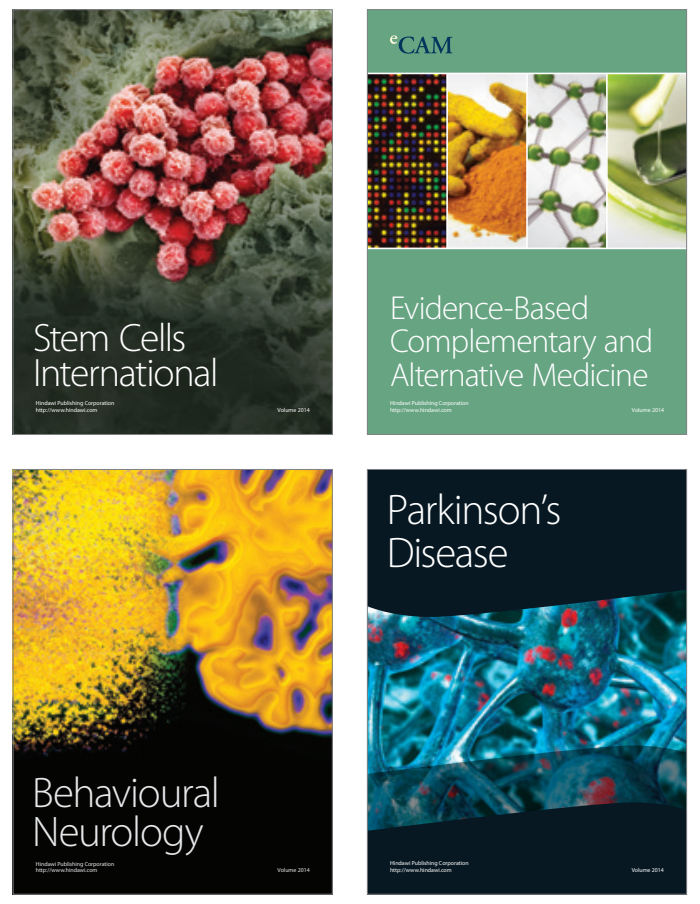
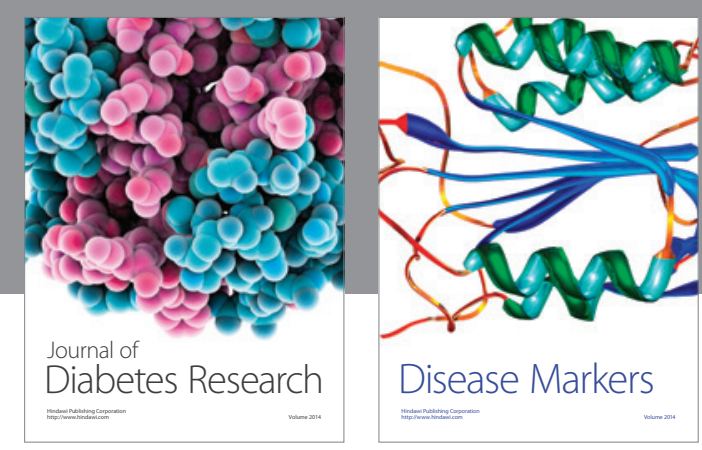

Disease Markers
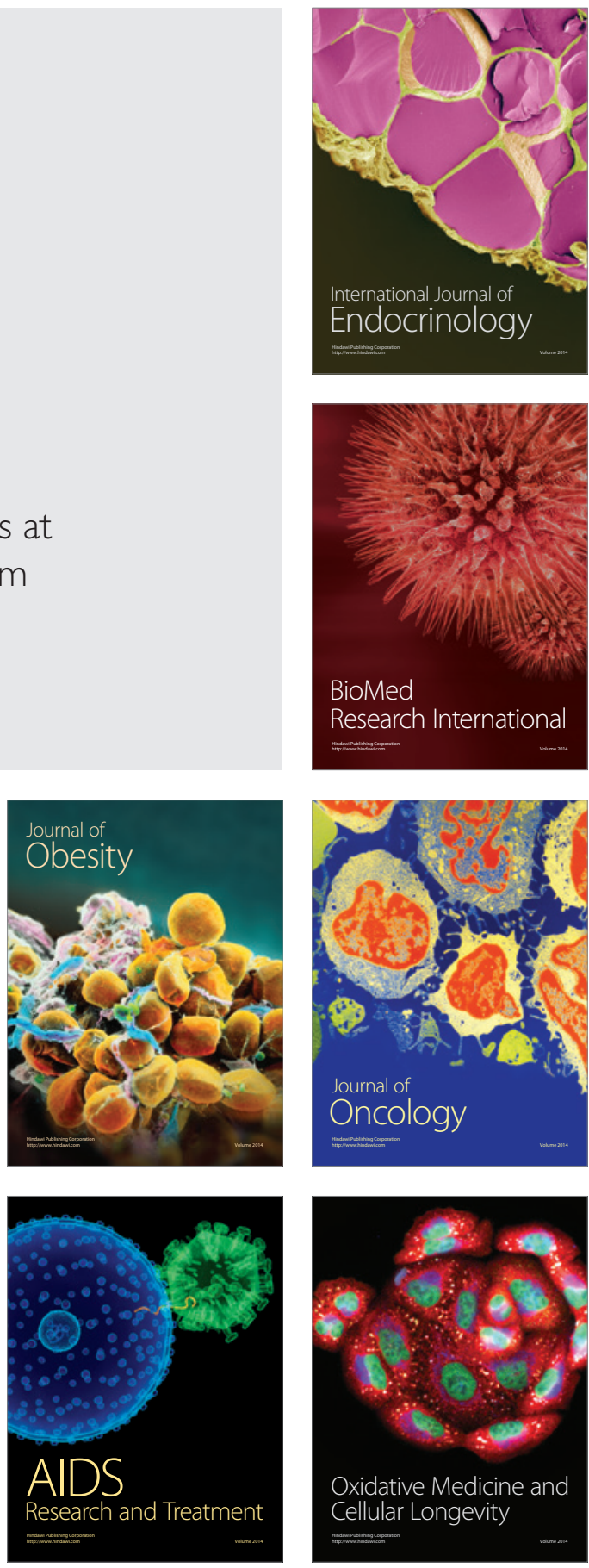